一論文—

(日本化学会誌, 1988, (9), p. 1583 1586)

(C) 1988 The Chemical Society of Japan

\title{
静電場噴霧を用いる液体クロマトグラフィー用 焱光検出器の試作
}

\author{
（1987 年 8 月 12 日受理）
}

\author{
岡 崎 重 光*・鈴 木 義 仁
}

\begin{abstract}
静電場噴娚法を用いて，ミクロ液体クロマトグラフィーの炎光検出器を試作した。溶離液を静電場噴 霧法で微粒化し然焼させ，還元炎中で硫黄の発光を利用して，硫黄を含む化合物のクロマトグラムを炎 光検出する。そのさい，溶離液の有機溶媒による妨害をともなう。この妨害を除くためダブルフレーム 型の燃焼装置とした。一段目のバーナーでは酸素過剩炎として有機物を完全然焼させ，ついで二段目の バーナーの還元炎中で硫黄の発光を安定化させた。水やプロパノール類などの極性の大きい溶離液は容 易に微粒化されるが, ベンゼン，トルエンなどの極性の小さい液体の微粒化は困難であった。プロパ， 一ル類の場合は水素と空気で安定に然焼するが, 含水量の多い溶離液では不安定な燃焼となる。空気を 酸素に変えて安定化をはかった。内径 $0.5 \mathrm{~mm}$, 長さ $110 \mathrm{~mm}$ の ODS カラムを使用し, 40\% (v/v) 2-プロパノール/水, 流速 $8 \mu \mathrm{l} / \mathrm{min}$ で, 4 種の alkyl phenylthiocarbamates それぞれ $0.5 \mu \mathrm{g}$ の混 合物のクロマトグラムが得られた。
\end{abstract}

\section{1 緒言}

ミクロ液体クロマトグラフィー（以下，ミクロ HPLC と略記 する）使用できる検出器としては，ピークの広がりを小さくす るため内容積の小さな検出器が必要である。また，微量成分の検 出にあたっては高感度でかつ選択性の高い倹出器が必要である。 炎光検出器 (以下 FPD と略記する) は硫黄化合物に対して高選 択的であるためガスクロマトグラフィーで利用されている。しか し HPLC では硫黄化合物の発光時に溶離液の燃焼にともならク エンチング（消光）現象が起こるため十分な利用にいたっていな い。また燃狫時の溶離液の気化方法にも検討の必要がある。本研 究では, 静電場噴算法”（以下，ES 法と略記する）を用いて, 燃 焼炎中にミクロ HPLC からの溶離成分を霧状に唄出させて然焼 させ，炎の中での硫黄化合物から発光を検出する方法を試みた。 FPD をHPLC に応用しょ5とする研究では，多量のガスを流入

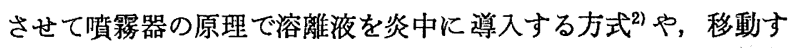
るワイヤー上に溶雁液を付着させて炎中に導入する方法”などの 研究がある。またミクロ HPLC についても多量のガスによって 霧状として炎中へ導き，炎光検出する原理の報告がある゙う。また これらについての総説)もある。しかしミクロ HPLCからの溶離 液の全量を效率よく炎の中に導入し, かつ十分な感度と安定性を

山梨大学工学部工学基礎教室, 400 甲府市武田

1) 松本 勲, 桥本武男, 静電気学会誌, 4, 202(1980).

2) B. G. Julin, H. W. Vandenborn, J. J. Kirkland, J. Chromatogr., 112, 443(1975).

3) K. Slais, M. Krejci, ibid., 91, 181(1974).

4) V. L. McGuffin, M. Novotny, Anal. Chem., 53, 946 (1981).

5) L.S. Ettre, J. Chromatogr. Sci., 16, 396(1978).
もつ FPD とはなっていない。これは多量のガスによって蓩状と する方法に原因がある。

著者は既報ので，ES 法を利用してけいそら土を付着させた石英 棒表面に, ミクロ HPLC の溶離液を効率よく付着させることに 成功した。ES 法は静電場をノズルと電極間に印加することによ って, 溶離液が微小な液滴となってノズルから噴出することを利 用したものである。本報はこの ES 法を利用してクロマトグラフ 1ーの溶離液を微粒化し, また, 溶媒によるクエンチングを防止 するため二段階燃焼させて炎光検出する方法を研究し, 硫黄によ る発光のクロマトグラムを得ることに成功した。

\section{2 実験}

\section{1 装 置}

実験に使用したミクロ液体クロマトグラフィーの概略図を図 1 に示す。検出器の主体となる燃焼装置部分は, GC で用いられて いる燃焼装置を改良して作製した。それを四 2 に示す。四 2 のよ らに, 移動相の有機物溶媒による消光を減少させるため, 二段階 の燃焼を行なら方法を採用した。すなわち一段目の燃焼は酸素過 剩の然㜔条件ですべての有機物を燃烇させる。ついで二段目の炎 は水素過剩の燃焼条件とすることによって, 硫黄元素による発光 を取り出すように工夫した。図2 の斜線部分はテフロンで, 命却 水を通す部分はニッケルとし，他はほとんどステンレススチール で作製した。また，二段目の炎の中での硫黄元素の発光は，外光 が入らないよらにしゃへいして，干歩フィルター（394 nm バン ドパスフィルター）と光電子増倍管を取り付けて検出した。さら に完全に燃焼しない液滴が下炎を通過して直接上炎に入るのを防 ぐため, 上炎に対して下炎の燃焼部分を $6^{\circ}$ 打よび $10^{\circ}$ 傾斜させ

6) 岡崎重光, 滰本 整, 鈴木義仁, 分析化学, 34, 180(1985). 


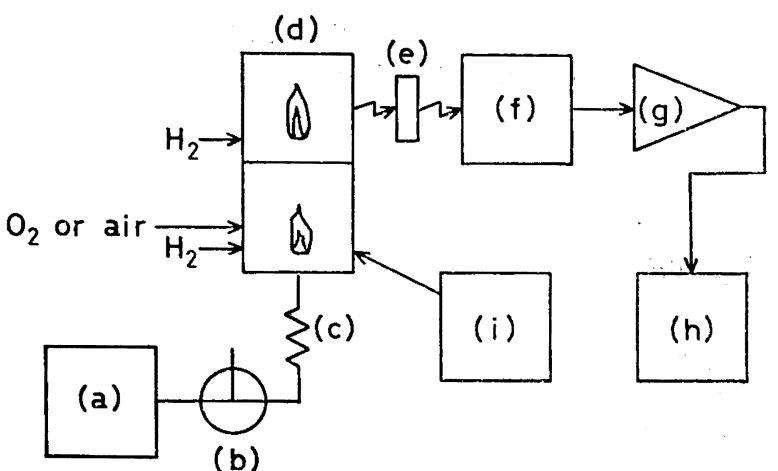

Fig. 1 Schematic diagram of micro HPLC

(a) : Micro HPLC pump : FAMILIC-100 (Jasco)

(b) : Injector : MODEL 5001 (EYELA)

(c) : Micro column : ODS $0.5 \mathrm{~mm}$ (in diameter) $\times 110$ $\mathrm{mm}$ (Jasco)

(d) : Double flame burner : Fig. 2

(e) : Interference filter : $394 \mathrm{~nm}$

(f) : Photomultiplier : part of FPD-D 7 (Shimadzu)

( $\mathrm{g}$ ) : Amplifier : The parts of FPD-D 7 (Shimadzu)

(h) : Recorder : $10 \mathrm{mV}$ full scale (Rikadenki)

(i) : High voltage supply : KT $010 \mathrm{KP}$ (Towakeișoku)

た装置も作製した。しかし記録計に現われる信号で見るかぎり， 傾斜角度 $0^{\circ}$ のものを含めた 3 種の装置で, 汪とんど差が見られ ながった以後の実験には $0^{\circ} ま た は ~ 6^{\circ}$ の装置を使用した。

図 2 の装置で電極と溶離液の質出するステンレスス, ルー製毛 細管の距離は 1.5 2 mm, 印加電圧は 2500〜3500 V, 毛細管の 先端は外径 $0.25 \mathrm{~mm}$ 内径は $0.12 \mathrm{~mm}$ で, 電極には直径 $2 \mathrm{~mm}$ の穴があけでる。最適条件は溶離液の組成, 流速などによって 多少異なる。たとえば, 溶離液にプロパフール類を用い流速 $8 \mu l$ $\min$ のとき, 下炎の水素流速は $35 \mathrm{ml} / \mathrm{min}$, 上炎の水素流速は $160 \mathrm{~m} l / \mathrm{min}$ で, 空気流速は $280 \mathrm{ml} / \mathrm{min}$ 程度が適当であった。ま た溶離液に $40 \%(\mathrm{v} / \mathrm{v}) 2-2^{\circ}$ ロパノール/水を用い流速 $8 \mu \mathrm{l} / \mathrm{min}$ のときは, 下炎の水素流速は $72 \mathrm{ml} / \mathrm{min}$ ，上炎の水奏流速は 109 $\mathrm{m} l / \mathrm{min}$ で, 酸素は $60 \mathrm{ml} / \mathrm{min}$ 程度が適当であった。

2.2 試 料

本研究で発光を観察するための硫黄化合物として, へキサナー ルニチオセミカルバソンを使用した。またミクロ HPLC の分離検 出にあたっては, 紫外検出器で得られるクロマトグラムと本装置 によるクロマトグラムとの比較ができるよらな化合物として, 各 種の alkyl phenylthiocarbamates を使用した。それらの構造式を 図3に示す。これらの試料はいずれる著者が常法にしたがって合 成したのち，再結晶による精製を行なった。試料はいずれるプロ パノールに溶解して濃度 $1 \mathrm{mg} / \mathrm{ml}$ 程度の溶液としたのち, この $0.1 \sim 1.0 \mu l$ を分取してクロマトグラムを得た。試料の注入はア イラ製ミクロ注入器を使用した。

\section{3 結果と考察}

\section{1 液体の微粒化}

水, メタノール, ェタノール, プロパノール類, プタノール類 などの溶媒は静電印加することによって, 微小液滴となった。し かし，ヘンビン，トルエンなど極性の小さい溶媒は，微粒化が困

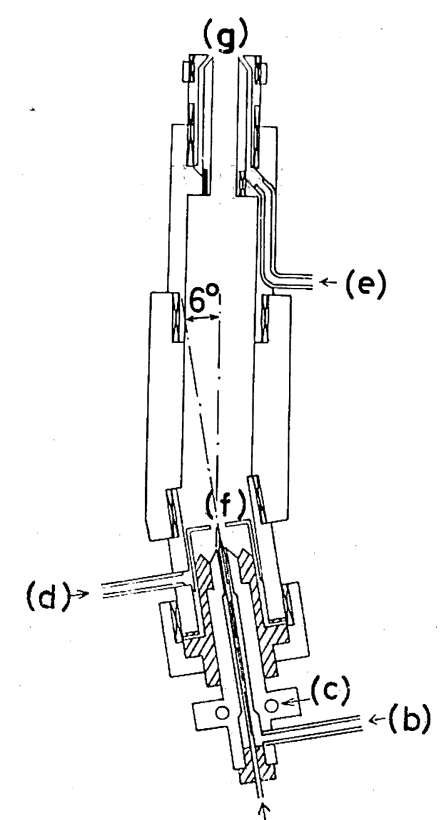

(a)

Fig. 2 Double flame burner

a : Eluent, b: Hydrogen gas, c : Cooling water, $\mathrm{d}$ : Air or oxygen gas, e: Hydrogen gas,

$f$ : Lower flame, $g$ : Upper flame

\section{[A]}

$\mathrm{CH}_{3}\left(\mathrm{CH}_{2}\right)_{4} \mathrm{CHNNHCSNH}$

[B]<smiles>[R]OC(=S)Nc1ccccc1</smiles>

Fig. 3 Structure of sample

[A]: Hexanal thiosemicarbazone,

[B]: Alkyl phenylthiocarbamate

難であった。このよらな極性の小さい溶媒にメタノールを10\% 程度添加すると，微粒化が可能となっだ。メターール溶媒が静 電場の印加により微粒化しているときのノズルの先端の写真を図 4 に示す。ステンレススチールの先端に円錐形となったメタノー ルが存在し，その先から電場から引き出されている。写真は読み 取り顕微鏡を通して $35 \mathrm{~mm}$ カメラで撮影したるのである。液滴 のスピードは速く写真ではさらに拻大されているため, 液滴とし ては写らない。電極間隔が $1.5 \mathrm{~mm}$ のとき 1700 から $3000 \mathrm{~V}$ ま で電圧を上げると，メタノール液体の円錐形は次第に小さくな り，3000 V 以上に電圧を上げるとステンレススチール管の先端 から 2 3 本の液滴列が発生し，たがいに反発するため液滴が周 囲に飛散するのが観测された。また, $3000 \mathrm{~V}$ 以上では放電が起こ り始めるため次第に不安定となる。

7）岡崎重光，鈴木義仁，日本化学会第 47 春季年会講演予稿 集 I, p. 644 (1983). 


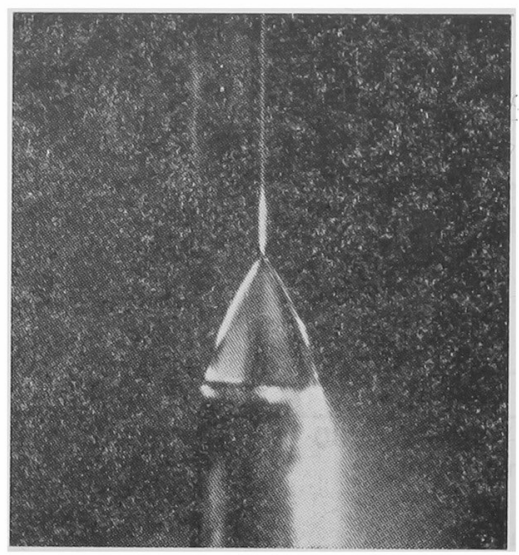

Fig. 4 Eluent shape at the tip of needle tube under high voltage field

o.d. of stainless steel tube $: 0.6 \mathrm{~mm}$, i. d. of stainless steel tube: $0.3 \mathrm{~mm}$, applied voltage : $2500 \mathrm{~V}$, flow rate of methanol : $8 \mu \mathrm{l} / \mathrm{min}$, distance between a stainless steel tube and an electrode : $3 \mathrm{~mm}$

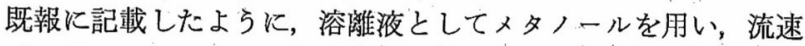
$16 \mu l / \mathrm{min}$ のミクロ HPLC の条件下では, 電荷を帯びた液滴を捕 集すると $10^{-10} \sim 10^{-8} \mathrm{~A}$ の電流が記録された (既報6)の p. 181 図 3 参照)。このことから，液滴は電荷を帯び，対極となっている 電極に微粒化して噴霧されることがわかる。印加電圧，ステンレ ススチール製毛細管と電極の距離, 液体の種頪, などを一定にた もつことによって定常状態となることがわかった。同じ電極間隔 で電圧を $3000 \mathrm{~V}$ 付近に上げるとステンレススチール製毛細管の 先端からコロナ放電が起こるようになる。本報で液滴を炎の中 で燃焼させるため, なるべく液滴は小さい方がよい。そこでコ口 ナ放電が起こるような高電圧の条件で静電暂霧を行なっている。

\section{2 溶離液の燃焼}

ミ゙クロ HPLC からの溶恢液の全量を直接水素炎中で安定に燃 笎させるためには，ステンレススチール製の毛細管の外径を細く することが重要である。毛細管として使用したものは，内径 0.12 $\mathrm{mm}$ の市肘注射針を研磨して先端の外径を $0.25 \mathrm{~mm}$ にしたも の, 外径 $0.2 \mathrm{~mm}$ 内径 $0.1 \mathrm{~mm}$ のニッケル管, 自製のパイレック スガラス製毛細管に電極としてタングステン線を通したものなど である。パイレックスガラス製の毛細管は，操作のさいに折れや すいこと，毛細管の先端を直角に切断することが困難なこと，拉 よび毛細管の冷却が十分に行なわれず熱に弱いことなどのため, 燃焼装置として長時間の使用は困難である。

また，水冷したニッケル管で，燃焼装置の中心部位位置する毛 細管の外周を围み，冷却するよう工夫した。しかし，冷却がまだ 不十分なため, 溶離液に沸点の低いメタノールを用いた場合, 不 安定な燃燒となった。エタノール, プロパノール類, ブタノール 類を溶離液とした場合には安定に燃罃した。プロパノール類に水 を加觉ると，水の增加とともに燃焼が不安定となった。この場合 には，空気を酸素に置き換えることで安定な燃焼が得られた。

\section{3 検 量 線}

注入装置は $0.1,0.2,0.3,0.4,0.5,1.0 \mu \mathrm{l}$.の内容積をもつ インジェクターを使用した。へキサナールニチオセミカルバゾン の結晶を科り取り, 1ープロパノールに溶かして種々の浱度の標準

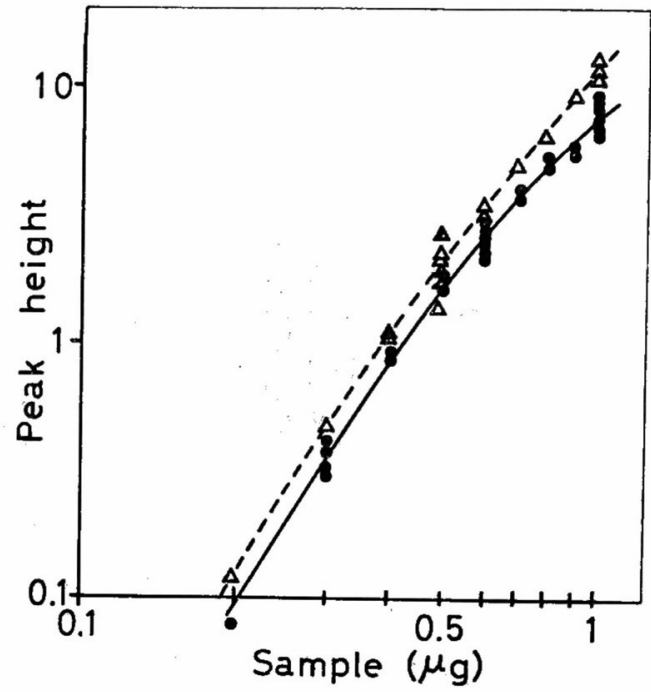

Fig. 5 Logarithmic plot of FPD signals

Sample: Hexanal thiosemicarbazone Mobile phase ; $\bigcirc$ : 1-Propanol, $\triangle$ : Ethanol Applied voltage $: 3000 \mathrm{~V}$

溶液を調製した。この溶液の $0.1 \sim 1.0 \mu l$ 注入したときのクロマ トグラムのピーク高さを求め, 注入した化合物重量と FPD の応 答性沉ついての関係を求めた。

図 5 は, ヘキサナール=チオセミカルバン゙ンの注入量が 0.2 か ら $1 \mu \mathrm{g}$ までの範囲について, 移動相に 1-プロパノールとェタ, ールを使用し，HPLC を行なった場合のピークの高さの測定結果 である。検出限界はへキサナールニチオセミカルバゾンで $0.2 \mu \mathrm{g}$ 程度であった。試料中の硫黄の割合は重量で $18.5 \%$ であるから， 硫黄の検出限界としては $0.04 \mu \mathrm{g}$ 程度になる。クロママグラム上 で求めたピークの高さは硫黄化合物重量のほぼ $2 \sim 3$ 乗に比例す るような信号が得られた。これは，著者がすでに GC の炎光検出 器による硫黄化合物の応答珄について報告した結果と年9)、ほぼ 類似の挙動をするものとなった。 $\mathrm{S}_{2}$ による発光が GC の場合 1.69 2.00 乗となるのに対しで, , 本研究の絬果は, 二段フレー ムとしたにもかかわらず，溶離液のプロパノール類によるクエン チングの効果が大きいためと考学ている。

\section{4 硫黄化合物の FPD クロマトグラム}

propyl phenylthiocarbamate, butyl phenylthiocarbamate, pentyl phenylthiocarbamate, 拉よび hexyl phenylthiocarbamate, 各 $0.5 \mu \mathrm{g}$ の混合物を注入したときのクロマトグラムを図 6 の (A) 示す。信号の取り出しにあたって, $10 \mathrm{k} \Omega$ の抵抗と $190 \mu \mathrm{F}$ の コンデンサーを使用して平滑回路とし， イイズの平均化を行なっ た。また, $280 \mathrm{~nm}$ と合わせた紫外検出器 (UV) を用いて同一の 試料を注入して得られたクロマトグラムを図 6 の (B)に示した。 カラムから検出器までの長さ, カラム温度などに少し差があるた め,クロマトグラムは完全には一致しないが, 図6からミクロ HPLC の FPD として十分に機能していることがわかる。溶離夜 が 40\% (v/v) 2-プロパノール/水であるため, 注入後 3 分ほどで

8) T. Sugiyama, Y.Suzuki, T. Takeuchi, J. Chromatogr., 77, 309(1973).

9) M. Maruyama, M. Kakemoto, J. Chromatogr. Sci., 16, 1(1978). 


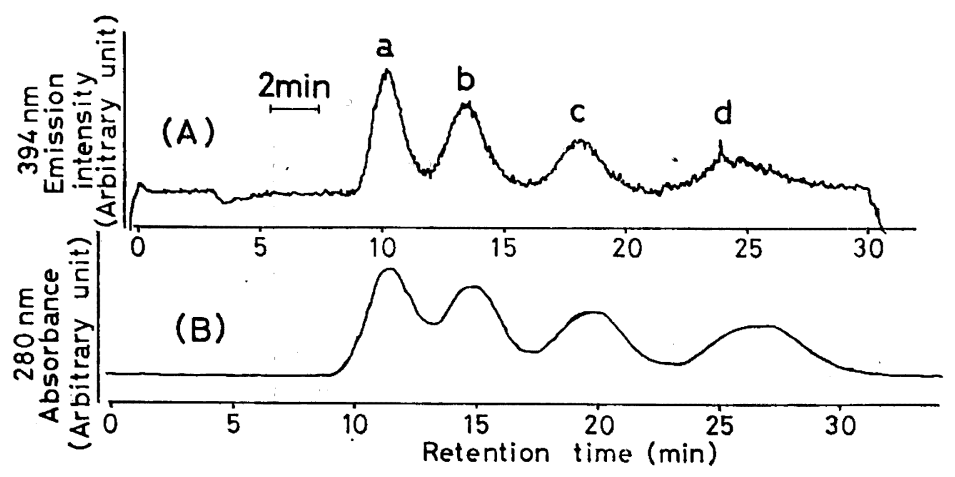

Fig. 6 Chromatography of four components

(A) : Chromatography obtained by this FPD method, Applied voltage : $3000 \mathrm{~V}$

(B): Chromatography obtained with UV monitor

a : Propyl phenylthiocarbamate $0.5 \mu \mathrm{g}$, b : Butyl phenylthiocarbamate $0.5 \mu \mathrm{g}$,

c : Pentyl phenylthiocarbamate $0.5 \mu \mathrm{g}$, d : Hexyl phenylthiocarbamate $0.5 \mu \mathrm{g}$

Mobile phase : $40 \%(\mathrm{v} / \mathrm{v}) 2$-propanol/water

試料の溶媒が検出器に達して燃焼状態が変化しそそれがベースラ インの変化として検出されている。

\section{4 結 論}

ミクロ HPLC 用炎光検出器を試作した。この検出器では, 溶 離液として使用するェタノール，プロパノール類，ブタノール類 を, 静電場によって微小液滴として効率よく燃焼させることがで きる。しかし，ヘンン゙ン，トルェンなど極性の小さい液体を溶離 液として用いる場合には，微粒化は困難である。また溶離液の， ズル内での気化を防ぐため, 然焼装置の毛細管は冷却する必要が ある。内径 $0.5 \mathrm{~mm}$ 長さ $110 \mathrm{~mm} \mathrm{SS}-10-O D S$ (日本分光) カラ

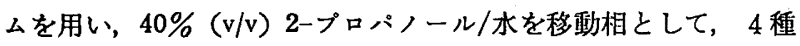
の alkyl phenylthiocarbamates 混合物のクロマトグラムから硫黄
化合物の本装置による応答性を求めた。また, へキサナールニチ オセミカルバゾンでの検出限界は $0.2 \mu \mathrm{g}$ であった。

本研究を進めるにあたって，インクジェットプリンターについ $\tau$, 山梨大学工学部機械工学科藤井朝信氏, 電気工学科清弘智昭 氏に助言を得たことを付記して感謝いたします。

本研究の一部は日本化学会第 47 春季年会 (1983 年 4 月) $)^{7)}$, 第 49 春季年会 $(1984 \text { 年 } 4 \text { 月 })^{10)}$ ，第 50 春季年会 $(1985 \text { 年 } 4 \text { 月 })^{11)}$ で 発表した。

10）岡崎重光, 鈴木義仁, 日本化学会第 49 春季年会諈演予稿 集 I, p.381 (1984).

11）岡崎重光, 鈴木義仁, 日本化学会第 50 春季年会丵演予稿 集 I, p. 618 (1985).

\title{
Flame Photometric Detector of Micro Liquid Chromatography by Means of Electrospray of Eluent
}

\author{
Shigemitu ОкаzакI* and Yoshihito Suzuki \\ Faculty of Engineering, Yamanashi University; Takeda, Kofu-shi 400 Japan
}

A flame photometric detector (FPD) for micro liquid chromatography has been developed, where the eluent was introduced into FPD by an electrospray technique. This method is useful to detect such agricultural chemicals as contain sulfur and do not have UV absorbance. The quenching due to organic solvent was decreased by using such double flame burner similar to be used in gas chromatography. 1-Propanol and 2-propanol used as eluent were nebulized and burned stably in hydrogen-air flame, but not for less polar liquids such as benzene and toluene by the electrospray method. On the other hand, 40\% (v/v) 2-propanol/ water did not burned stably in hydrogen-air flame, but burned stably in hydrogen-oxygen flame. The chromatograms of four alkyl phenylthiocarbamates were obtained with the ODS column $(0.5 \mathrm{~mm}$ in i.d. and $110 \mathrm{~mm}$ in length, eluent: $40 \%$ (v/v) 2-propanol/water, flow rate $: 8 \mu \mathrm{l} / \mathrm{min}$ ) coupled with FPD detection. The optimum working conditions of FPD were as follows : flow rate of hydrogen for lower flame and upper flame were $72 \mathrm{~m} l / \mathrm{min}$ and 109 $\mathrm{m} l / \mathrm{min}$, respectively, and flow rate of oxygen was $60 \mathrm{~m} l / \mathrm{min}$. The detection limit of hexanal thiosemicarbazone was $0.2 \mu \mathrm{g}$. 